\title{
GREENHOUSE GAS EMISSIONS PRODUCED IN AGRICULTURE SECTOR IN EU
}

\author{
Mariana Dubravská ${ }^{1}$ \\ Elena Širá ${ }^{2}$
}

DOI: https://doi.org/10.31410/ITEMA.2020.257

\begin{abstract}
Each economy must adapt its activities to the protection of the environment. It is now an essential part of everyday life, in the face of various climate changes. The Europe 2020 strategy sets out a set of objectives in the EU, including those promoting environmental sustainability, called sustainable growth. The aim of the paper is to determine, if the performance of the country, in the area of greenhouse gas emissions reduction is adequate to the strategy Europe 2020. In the analysis of greenhouse gas emission reductions, we will also focus on the agriculture sector and compare the development over time with the development in other EU countries. The analyzed period is 10 years, from 2009 - 2018. The article investigated the performance of greenhouse gas emissions in the example of EU (including the Great Britain) countries.
\end{abstract}

Keywords: EU, Greenhouse gas emissions, Agriculture, Europe 2020.

\section{INTRODUCTION}

I

n today's world, sustainability issues are becoming more emergent. A common attribute among the different approaches to defining this concept is the orientation towards the future. The sustainability economy is usually based on the idea of resource efficiency. Because a sustainable economy is about a long-term future that is largely unknown. It is therefore necessary to answer questions, that can ensure the long-term stability and growth of the country.

The concept of sustainable development is quite dynamic. This means that this issue can be explored from several perspectives (Sinakou et al. 2019). From the point of view of most theoretical approaches, there are three components to the issue of sustainable development: environmental, economic and social. Of these three aspects, the environmental dimension of sustainability has so far received the most attention. If people want to live in a prosperous country with a healthy environment, the main trends of today's world need to be addressed (such as changes in demography, changing consumer patterns, social change, changing the use of natural resources and increasing pressure on natural resources and ecosystems, etc.). which may worsen the situation.

Department of Economics and Economy, Faculty of Management, University of Prešov, 08001 Prešov, Slovakia

2 Department of Economics and Economy, Faculty of Management, University of Prešov, 08001 Prešov, Slovakia 


\section{THEORETICAL BACKGROUND}

\section{Europe 2020 and Sustainable growth}

In 2010, the European Commission officially issued a Europe 2020 Strategy for Smart, Sustainable and Inclusive Growth. It succeeds the Single European Market program (19861992) and the Lisbon Strategy (2000 - 2010), decided by the European Council on 26 March 2010, chaired by President Herman Van Rompuy. The Lisbon Strategy, from the substantive perspective, was not a new initiative, as before there had been attempts to introduce various processes in order to recover and reorganize the functioning of the EU (Stec, Grzebyk, 2018). The Lisbon Strategy aimed to transform Europe into the most competitive economy in the world (Silander 2019), but according to some problem areas and other problems that arose during implementation, it was not as successful as expected. The Europe 2020 strategy is the EU strategy for sustainable and inclusive growth, for fighting the structural weaknesses of the European economies, and for improving their competitiveness. (Radulescu et al., 2018)

The Europe 2020 strategy set out the main goals to be achieved in the EU countries by 2020 . It is up to the Member States to take action at national and regional level to try to achieve these goals (Radulescu et al. 2018). In order to guide member states' efforts and manage progress, only a limited number of headline targets had to be set (Abad-Segura, González-Zamar, Belmonte-Ureña, 2020). These targets are representative, measurable, able to reflect the diversity of situations in the Member States and based on sufficiently reliable data for comparison purposes (Barroso 2010). In order to ensure that each Member State adapts the Europe 2020 strategy to its specific situation, the Commission proposes that EU objectives be reflected in national targets and trajectories. For each of these growths, targets have been set. Some targets are the same for all member states. Other targets are adapted to the conditions of individual member countries, respecting the specifics of the economy. And the last group consists of targets, where all EU countries participate, according to their possibilities, in fulfilling the targets and achieving the set value by aggregate.

This strategy focuses on three key areas. They are sustainable, inclusive and smart growth. (Širá 2017) Sustainable growth is explained as a set of measures aimed at promoting a greener and more competitive, resource-efficient economy (Witkowska-Dąbrowska, 2018). Sustainable growth means building a sustainable and competitive resource-efficient economy and strengthening competitiveness. This approach will help the EU prosper in a low-carbon, resource-constrained world, while preventing environmental degradation, biodiversity loss and unsustainable resource use (Barroso 2010).

Sustainable growth through the transition to a greener economy refers to building a European economy of resource efficiency and sustainability (Adamišin et al. 2016), and staying global competitive based on greener technologies. The main themes addressed by this strategy are climate, energy, mobility and competitiveness. This requires innovative European political enterprise to promote competitive entrepreneurship, new network businesses and a consumer culture that values resource efficiency and a greener, low-carbon economy. (Silander 2019).

The Commission stated the importance of continued open trade of exports and imports but also that Europe had to become more competitive and with higher productivity of partner states (Anastasiou, Marietta, 2020). Europe must also continue its early initiatives to become a global green economic actor by pushing for green technologies to safeguard resource efficiency. The push for green technologies would lead to fulfilled climate change goals, with significant 
decreased emissions, but would also open up for a transition to a new environmentally friendly economy of new innovations, products and services that all together would create new jobs and a growing economy. A transition to a greener economy would also lead to lowered costs for import of expensive oil and gas and would be beneficial for European security because of lowered dependency on specific foreign governments. (Barroso 2010).

Sustainable growth would be approached based on three climate change and energy targets.

The so-called 20-20-20 targets (Stec, Grzebyk, 2018) set out by the EU include:

- reducing greenhouse gas emission by 20 percent,

- increasing renewable energy in gross final energy consumption by 20 percent,

- increasing energy efficiency by 20 percent. (Barroso 2010).

Such targets not only provide for important measures against ongoing climate change, but also provide new jobs in a transformed, greener economy with green products and services and makes the EU become a green, global competitive actor (Silander 2019). This sustainable growth will require the implementation of countries' emission reduction commitments in a way that maximizes benefits (Stăncioiu, Costea-Dunărinţu, Păduraru, 2017) and minimizes costs, including through the dissemination of innovative technological solutions. In addition, EU countries should focus on decoupling growth from energy use and becoming more resourceefficient economies, which will not only give Europe a competitive advantage but also reduce its dependence on foreign sources of raw materials and commodities (Barroso 2010).

\section{Agriculture}

Greenhouse gas emissions from agriculture, including crop and livestock production, forestry and associated land use changes, are responsible for a significant fraction of anthropogenic missions, up to $30 \%$ according to the Intergovernmental Panel on Climate Change. (Tubiello et al. 2013) Among the important issues for agriculture's sustainability is greenhouse gas emissions, and their impact on climate. Whereas agriculture can benefit from a warmer climate in some parts of the world through longer growing seasons, agriculture could also be negatively affected in many regions by drought, flooding, pests and/or diseases. In addition, greenhouse gas emissions represent an indirect economic loss for the farmers (Verge, De Kimpe, Desjardins, 2007).

Globally, the emissions of carbon dioxide, methane and nitrous oxide from agriculture account for approximately one-fifth of the annual increase in radiative forcing, and for one-third when land use changes are included. The agricultural sector contributes with significantly $\%$ of the total anthropogenic emissions of $\mathrm{CH}_{4}$ and $\mathrm{N}_{2} \mathrm{O}$. Land use change, crops and cropping systems have various effects on the weathers (Verge, De Kimpe, Desjardins, 2007).

Three steps according to Franks \& Hadingham (2012) are required to successfully and efficiently reduce greenhouse gas emissions from agriculture:

- identification of the most greenhouse gas polluting farms,

- determining appropriate mitigation options for these farms,

- selection between these options on the basis of their cost effectiveness.

Carbon footprints of a sample of farms together with an analysis of the Kyoto Protocol show the difficulties encountered at each step. These difficulties are caused by: 
- failure to agree which functional unit to use to measure GHG emissions and pollution swapping;

- weaknesses in the Kyoto Protocol's territorial/production-based accounting methodology,

- lack of cost-effectiveness data (Franks, Hadingham, 2012).

\section{METHODOLOGY}

The aim of the paper is to determine, if the performance of the country, in the area of greenhouse gas emissions reduction is adequate to the strategy Europe 2020. We assessed the fulfilment of the goal set out in the section of sustainable growth in the Europe 2020 strategy. The goal set the reducing greenhouse gas emission by 20 per cent compared to year 1990 .

Because the strategy Europe 2020 is the strategy obligatory for all EU member states, we analyzed the example of all EU countries (including the Great Britain). The analyzed period is 10 years, from 2009 - 2018.

In the analysis of greenhouse gas emission reductions, we will also focus on the agriculture sector and compare the development over time with the development in other EU countries.

Based on the approaches of various authors, we have elaborated theoretical background. These characterize the researched area and define the goal of the work. When processing the next part of the paper, we worked with data from Eurostat.

\section{RESULTS AND DISCUSSION}

In the previous section, we pointed out the importance of sustainability, especially in the long term and for maintaining the current state for the future, and its improvement in areas where this is possible. The environment and its protection are an area regulated by legislation. This area and the possible damage in it, have a far-reaching impact on many other areas of people's lives. Therefore, it is sustainable growth dedicated to the environment, which is an important area that has also come to the head of the Europa 2020 strategy. It is a commitment for all EU member states to support improvements in this area, as well as various innovations sparingly to the environment.

The inclusion of resource efficiency and a low-carbon society among European policy priorities is the result of the recognition, that the prevailing model of economic development based on the fluent growth of resource use and harmful emissions, is unsustainable in the long run. (Chovancová 2015)

Rising greenhouse gas emissions are causing increased concentrations of these gases in the atmosphere. This in turn causes the earth's surface to overheat, leading to climate change. This is the physical side of the problem of climate change. This problem can also be seen from a socio-economic point of view. In this case, it is the relationship between the economy and the emissions generated. The economy produces greenhouse gas emissions mainly through various combustion processes, which are necessary to obtain the energy needed in the production process. (Habrman 2012)

The Europa 2020 strategy has set as one of the goals of sustainable growth a reduction in greenhouse gas emissions of at least $20 \%$ compared to the values achieved in 1990. These values for the EU countries in the period 2009 - 2018 are stated in Table 1. The aim is for all EU states to had the values for this indicator of 80 or lower in 2020 . The years in which the individual countries met the set value are indicated in the table. 
Table 1. Reduction of greenhouse gas emissions in \% of terms compared to 1990

\begin{tabular}{|c|c|c|c|c|c|c|c|c|c|c|}
\hline & 2009 & 2010 & 2011 & 2012 & 2013 & 2014 & 2015 & 2016 & 2017 & 2018 \\
\hline Belgium & 87,61 & 92,63 & 85,76 & 83,61 & 83,48 & 79,77 & 82,81 & 81,96 & 82,14 & 82,67 \\
\hline Bulgaria & 57,18 & 59,74 & 64,88 & 59,93 & 54,78 & 57,74 & 60,93 & 58,52 & 60,88 & 57,16 \\
\hline Czechia & 69,75 & 71,07 & 70,28 & 68,14 & 65,46 & 64,41 & 65,13 & 66,06 & 65,56 & 64,82 \\
\hline Denmark & 90,58 & 90,89 & 83,78 & 77,52 & 79,88 & 74,35 & 70,66 & 73,74 & 70,67 & 70,69 \\
\hline Germany & 74,05 & 76,64 & 74,73 & 75,25 & 76,68 & 73,49 & 73,8 & 74,17 & 73,22 & 70,44 \\
\hline Estonia & 41,18 & 52,3 & 52,48 & 49,89 & 54,46 & 52,5 & 45,22 & 48,98 & 52,26 & 49,98 \\
\hline Ireland & 113,15 & 112,47 & 104,76 & 105,23 & 105,41 & 105,34 & 109,56 & 113,34 & 113,29 & 113,6 \\
\hline Greece & 120,39 & 114,48 & 111,82 & 108,44 & 99,42 & 96,53 & 92,98 & 89,74 & 93,62 & 90,84 \\
\hline Spain & 130,96 & 126,21 & 126,38 & 123,77 & 114,87 & 115,77 & 119,83 & 116,51 & 121,49 & 119,74 \\
\hline France & 93,64 & 94,78 & 89,76 & 89,78 & 89,96 & 84,41 & 85,28 & 85,44 & 86,35 & 83,1 \\
\hline Croatia & 88,77 & 87,51 & 86,55 & 80,99 & 76,7 & 74,34 & 75,62 & 76,15 & 78,71 & 75,23 \\
\hline Italy & 98,19 & 100,44 & 98,12 & 94,43 & 87,63 & 83,71 & 86,3 & 85,8 & 85,05 & 84,41 \\
\hline Cyprus & 166,42 & 161,52 & 156,65 & 147,73 & 135,68 & 141,56 & 142,01 & 151 & 155,75 & 153,81 \\
\hline Latvia & 43,38 & 47,6 & 44,62 & 43,97 & 43,76 & 43,26 & 43,41 & 43,55 & 43,94 & 45,95 \\
\hline Lithuania & 41,68 & 43,44 & 44,67 & 44,59 & 42,09 & 42,02 & 42,64 & 42,77 & 43,24 & 42,64 \\
\hline Luxembourg & 97,71 & 102,38 & 100,82 & 98,04 & 93,98 & 91,21 & 88,67 & 87,98 & 90,88 & 94,16 \\
\hline Hungary & 69,04 & 69,43 & 67,72 & 63,62 & 60,64 & 61,33 & 64,95 & 65,48 & 68,25 & 67,82 \\
\hline Malta & 114,59 & 118,84 & 119,43 & 126,67 & 115,91 & 118 & 94,18 & 83,84 & 93,45 & 96,14 \\
\hline Netherlands & 93,84 & 99 & 92,95 & 91,04 & 90,96 & 87,73 & 91,63 & 91,57 & 90,78 & 88,58 \\
\hline Austria & 103,39 & 109,19 & 106,41 & 102,82 & 103,25 & 98,68 & 101,6 & 103,05 & 106,17 & 102,66 \\
\hline Poland & 83,13 & 87,1 & 86,9 & 85,35 & 84,64 & 82,02 & 82,73 & 84,56 & 87,7 & 87,42 \\
\hline Portugal & 125,57 & 118,96 & 116,78 & 113,69 & 110,69 & 110,82 & 118,01 & 115,32 & 123,78 & 118,9 \\
\hline Romania & 51,64 & 50,11 & 52,03 & 50,66 & 46,83 & 46,96 & 47,08 & 46,29 & 47,39 & 46,84 \\
\hline Slovenia & 105,09 & 105,2 & 105,23 & 102,21 & 98,51 & 89,22 & 90,18 & 94,69 & 93,47 & 94,35 \\
\hline Slovakia & 62,24 & 63,25 & 62,3 & 58,85 & 58,39 & 55,6 & 57,04 & 57,72 & 59,31 & 59,16 \\
\hline Finland & 96,18 & 107,11 & 96,8 & 89,12 & 89,8 & 84,01 & 79,06 & 83,16 & 79,59 & 81,41 \\
\hline Sweden & 83,56 & 91,82 & 86,07 & 82,01 & 79,79 & 77,4 & 77,11 & 76,99 & 76,52 & 75,28 \\
\hline UK & 77,67 & 79,33 & 73,68 & 75,63 & 73,97 & 69,03 & 66,9 & 63,76 & 62,7 & 61,59 \\
\hline
\end{tabular}

Source: own procession according to Eurostat

We can see, that some countries have the values of this indicator below the limit set in the Europe 2020 strategy throughout the observed period. These are the Baltic countries, then the V4 except Poland, Romania, Bulgaria and Germany. As the second group of countries, there are countries where during the analyzed 12 years, at least in some years, most often in recent years, values below the recommended limit were reached. These are Croatia, Belgium, Denmark, Finland, Sweden and the United Kingdom. The remaining countries have values higher than the recommended $80 \%$. On the positive side, however, we can see an effort in these countries to reduce these unfavorable values, such as in Malta, Slovenia, Italy and elsewhere. Cyprus $(154 \%)$ and Spain $(126 \%)$ have the highest average values over the period. On the contrary, the lowest average values were reached in Estonia (50\%) and Romania (51 $\%)$. 
The next table compares the volume of greenhouse gas emissions in agriculture. For better comparability of EU countries, we converted the data to \% of the total number. In this statement, we see big differences between countries.

Table 2. Greenhouse gas emissions in agriculture in \%

\begin{tabular}{|c|c|c|c|c|c|c|c|c|c|c|}
\hline & 2009 & 2010 & 2011 & 2012 & 2013 & 2014 & 2015 & 2016 & 2017 & 2018 \\
\hline Belgium & 8,15 & 7,65 & 8,20 & 8,22 & 8,27 & 8,87 & 8,56 & 8,52 & 8,64 & 8,48 \\
\hline Bulgaria & 11,11 & 11,35 & 9,08 & 10,12 & 11,97 & 12,50 & 11,71 & 12,99 & 12,30 & 13,00 \\
\hline Czechia & 5,79 & 5,56 & 6,12 & 6,28 & 6,49 & 6,65 & 7,00 & 7,02 & 6,90 & 6,43 \\
\hline Denmark & 16,46 & 17,03 & 19,02 & 20,02 & 18,99 & 20,87 & 20,29 & 19,51 & 21,10 & 20,14 \\
\hline Germany & 7,24 & 6,90 & 7,25 & 7,25 & 7,23 & 7,72 & 7,73 & 7,54 & 7,61 & 7,65 \\
\hline Estonia & 9,13 & 7,40 & 7,63 & 8,42 & 7,55 & 7,42 & 9,10 & 15 & 7,56 & 7,99 \\
\hline Ireland & 26,76 & 26,59 & 27,79 & 28,42 & 29,77 & 29,90 & 29,06 & 29,42 & 29,58 & 30,59 \\
\hline Greece & 7,01 & 7,65 & 7,64 & 7,75 & 8,31 & 8,06 & 8,55 & 8,89 & 8,54 & 8,72 \\
\hline Spain & ,29 & 11,91 & 11,65 & 11,46 & 12,49 & 13,06 & 12,88 & 3,43 & 13,24 & 13,39 \\
\hline France & 16,59 & 16,11 & 16,92 & 16,91 & 16,85 & 18,30 & 17,87 & 17,63 & 17,44 & 17,84 \\
\hline Croatia & 13,96 & 14,48 & 14,15 & 14,51 & 14,80 & 15,05 & 14,33 & 14,03 & 13,65 & 14,55 \\
\hline Italy & 6,60 & 6,39 & 6,56 & 6,82 & 7,49 & 7,82 & 7,65 & 7,79 & 7,47 & 7,72 \\
\hline Cyprus & 5,40 & 5,83 & 5,96 & 6,06 & 6,19 & 5,70 & 5,78 & 5,50 & 5,78 & 5,94 \\
\hline Latvia & 25,92 & 19,99 & 22,30 & 26,86 & 24,35 & 18,59 & 20,71 & 24,24 & 27,21 & 19,85 \\
\hline Lithuan & 33,37 & 39,55 & 38,71 & 40,25 & 39,68 & 39,00 & 30,66 & 27,47 & 25,98 & 26,10 \\
\hline Luxembou & 5,83 & 5,48 & 5,51 & 5,57 & 6,04 & 6,40 & 6,82 & 7,21 & 7,10 & 6,68 \\
\hline Hungary & 9,51 & 9,37 & 9,93 & 10,79 & 11,92 & 12,58 & 12,33 & 12,51 & 12,13 & 12,20 \\
\hline Malta & 2,39 & 2,28 & 2,16 & 2,07 & 2,27 & 2,23 & 2,99 & 3,41 & 3,00 & 2,99 \\
\hline Netherlands & 8,67 & 8,20 & 8,61 & 8,67 & 8,91 & 9,36 & 9,28 & 9,42 & 9,51 & 9,44 \\
\hline Austria & 9,54 & 8,98 & 9,37 & 9,57 & 9,38 & 10,08 & 9,78 & 9,79 & 9,48 & 9,79 \\
\hline Poland & 8,79 & 8,11 & 8,38 & 8,52 & 8,83 & 8,90 & 8,55 & 8,47 & 8,66 & 8,80 \\
\hline Portugal & 11,03 & 11,26 & 11,44 & 11,43 & 11,62 & 12,24 & 11,17 & 10,84 & 8,40 & 11,12 \\
\hline Romania & 18,79 & 17,48 & 16,76 & 17,34 & 19,85 & 20,10 & 20,34 & 21,03 & 20,21 & 21,66 \\
\hline Slovenia & 12,94 & 12,63 & 12,40 & 12,75 & 14,99 & 10,20 & 10,35 & 9,89 & 10,01 & 9,70 \\
\hline Slovakia & 6,26 & 5,96 & 6,37 & 7,13 & 7,65 & 8,03 & 7,69 & 7,80 & 7,19 & 7,29 \\
\hline Finland & 19,32 & 12,53 & 14,35 & 17,46 & 14,96 & 17,68 & 18,15 & 16,17 & 17,36 & 14,22 \\
\hline Sweden & 40,22 & 35,29 & 41,89 & 52,59 & 52,13 & 53,68 & 58,73 & 80,83 & 72,87 & 69,39 \\
\hline UK & 6,89 & 6,75 & 7,35 & 7,07 & 7,21 & 8,03 & 8,20 & 8,65 & 8,94 & 9,04 \\
\hline
\end{tabular}

Source: own calculations according to Eurostat

While in some countries the values of greenhouse gas emissions in agriculture are below $10 \%$ (Belgium, the Czech Republic, Germany, the Netherlands, Malta, Slovakia, the UK and others), in other countries the values are significantly higher. For example, Sweden has the highest values, around $70 \%$, then Ireland has values of about $30 \%$. Denmark, Lithuania and Romania still have values of $20 \%$. At the same time, these countries (highlighted in color) did not achieve exceptionally high values at all in terms of overall greenhouse gas emissions in tones among other countries. 
Graph 1. Total greenhouse gas emissions in thousands of tones

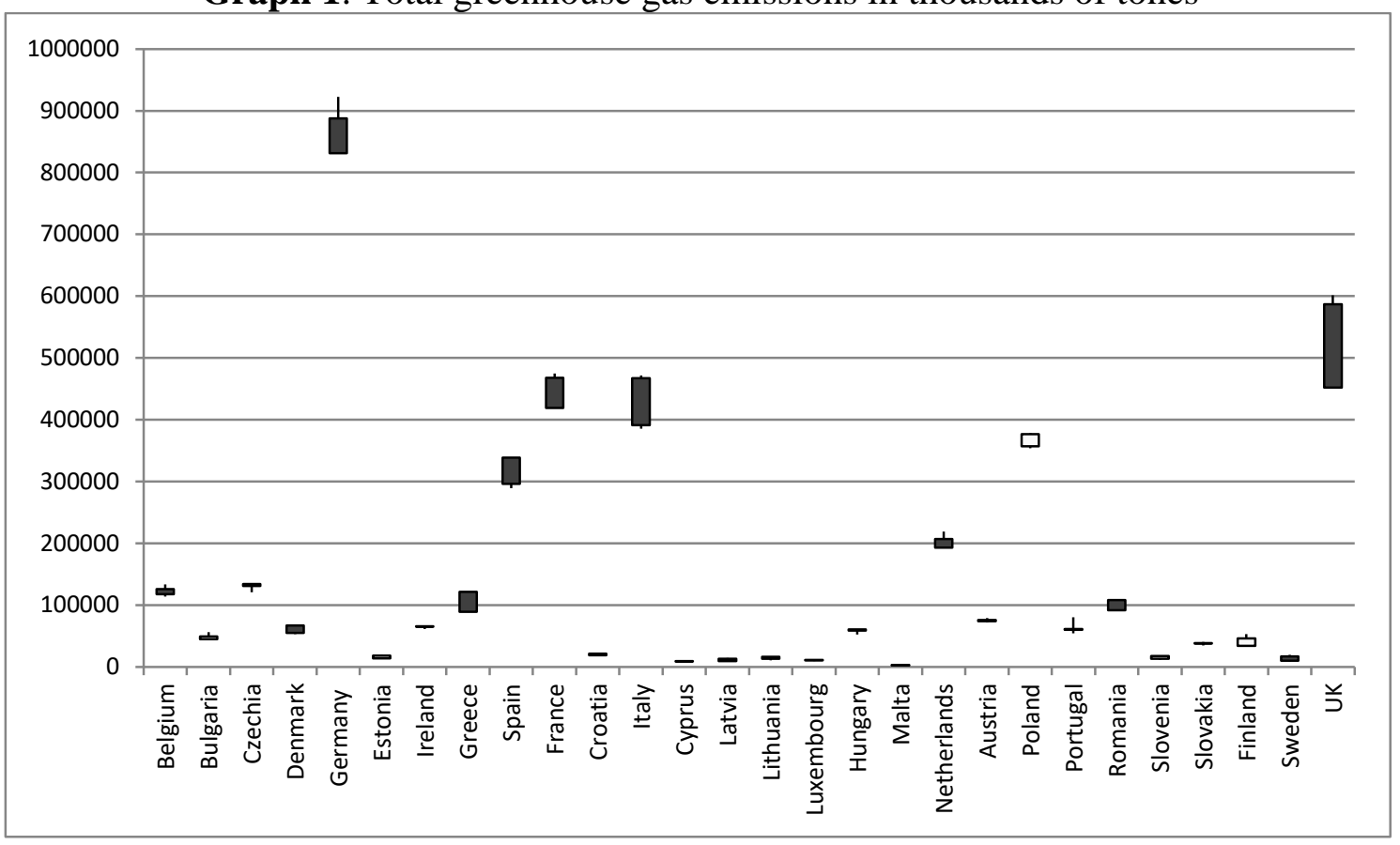

Statistical overview of achieved values of greenhouse gas emissions in thousands of tones in EU countries in the period $2009-2018$ is in graph 1. From the graph, we can see that the countries with the largest volume of greenhouse gas emissions are Germany, UK, Italy and France. The countries with the lowest volume of greenhouse gas emissions were Malta, Cyprus and Latvia. Between the EU countries are quite a great difference. It is caused by the size of the country, the amount of industry in the country and by other factors.

\section{CONCLUSION}

The Europe 2020 strategy is a strategy for smart, inclusive and sustainable growth. The greener economy is, according to climate changes and environmental protection, nowadays a priority for the most countries. EU countries, too. This strategy includes the elements of environmental protection, too. The sustainable growth is focus on the reduction of greenhouse gas emissions, too. This is the one of the three priorities of sustainable growth.

One of the three goals set the reducing greenhouse gas emission by 20 per cent compared to year 1990. In the year 2018, approximately the half of the EU member states, fulfill this goal. Some countries fulfill this goal for a whole analyzed period, some countries fulfill it in the last years.

Agriculture is one of the oldest industries. It has a permanent position in each country. But in recent years, its share of the country's GDP has been steadily declining. But this trend has not spread to the field of greenhouse gas emissions. There are countries where the share of greenhouse gas emissions in agriculture is significant (e.g. in Sweden), but overall, the country does not have a large volume of greenhouse gas emissions.

We have tried to point out these peculiarities in the article, but there is still a need for further analysis of this phenomenon. What may be the subject of further studies and research? 


\section{ACKNOWLEDGMENT}

This research was supported by the Scientific Grant Agency of the Ministry of Education: VEGA No. 1/0082/19

\section{REFERENCES}

Abad-Segura, E., González-Zamar, M. D., \& Belmonte-Ureña, L. J. (2020). Effects of Circular Economy Policies on the Environment and Sustainable Growth: Worldwide Research. Sustainability, 12(14), 5792.

Adamisin, P., Pukala, R., Chovancova, J., Novakova, M., \& Bak, T. (2016). Fulfillment of environmental goal of the strategy Europe 2020. Is it realistic; In 3rd International Multidisciplinary Scientific Conference on Social Sciences and Arts, SGEM (pp.181190).

Anastasiou, A., \& Marietta, P. (2020). Sustainable Development at the Frames of the Strategy “Europe 2020”. Theoretical Economics Letters, 10(03), 443.

Barroso, J. M. (2010). Communication from the Commission EUROPE 2020 - A strategy for smart, sustainable and inclusive growth. European Commission, Brussels

Franks, J. R., \& Hadingham, B. (2012). Reducing greenhouse gas emissions from agriculture: avoiding trivial solutions to a global problem. Land Use Policy, 29(4), 727-736.

Habrman, M. (2012). Štruktúrna dekompozícia emisií CO2 v slovenskej ekonomike. In Economic analysis \& policy group: working paper series, č. 6, 11 s. Bratislava: o.z. SOLIM

Chovancová, J. (2015). Hodnotenie vzt'ahu medzi ekonomickým rastom a produkciou emisií skleníkových plynov v krajinách V4 pomocou metódy decoupling. In Correspondence conference EAEP 2015 (p. 134).

Radulescu, M., Fedajev, A., Sinisi, C. I., Popescu, C., Iacob, S. E. (2018). Europe 2020 implementation as driver of economic performance and competitiveness. Panel analysis of CEE countries. Sustainability, 10(2), 566.

Silander, D. (2019). The European Commission and Europe 2020: smart, sustainable and inclusive growth. In Smart, Sustainable and Inclusive Growth. Edward Elgar Publishing.

Sinakou, E., Boeve-de Pauw, J., Van Petegem, P. (2019) Exploring the concept of sustainable development within education for sustainable development: implications for ESD research and practice. Environ. Dev. Sustain., 2019, 21(1), 1-10. DOI: 10.1007/S10668017-0032-8

Stăncioiu, A. F., Costea-Dunărinţu, A., \& Păduraru, D. (2017). The European union strategy for sustainable development in the energy sector. Calitatea, 18(S2), 431-434.

Stec, M., \& Grzebyk, M. (2018). The implementation of the Strategy Europe 2020 objectives in European Union countries: the concept analysis and statistical evaluation. Quality \& quantity, 52(1), 119-133.

Šrá, E. (2017). The Europe 2020-sustainable growth in V4 countries. SGEM International Multidisciplinary Scientific GeoConference, Vol 17, No.53, 893-899

Tubiello, F. N., Salvatore, M., Rossi, S., Ferrara, A., Fitton, N., \& Smith, P. (2013). The FAOSTAT database of greenhouse gas emissions from agriculture. Environmental Research Letters, 8(1), 015009.

Verge, X. P. C., De Kimpe, C., \& Desjardins, R. L. (2007). Agricultural production, greenhouse gas emissions and mitigation potential. Agricultural and forest meteorology, 142(2-4), 255-269. 
Witkowska-Dąbrowska, M. (2018). Evaluation of The Attainment of Environmental Goals in Sustainable Growth Regarding Gas Emission and Energy Consumption, as Defined for Poland in the Europe 2020 Strategy. Olsztyn Economic Journal, 13(4), 397-409. 